\title{
Korelasi Kontrol Glikemik dengan HDL dan Small-Dense LDL pada Penderita Diabetes Melitus dengan Komplikasi Jantung Koroner di RSUP Dr. Kariadi Semarang, Jawa Tengah
}

\author{
Srilaning Driyah ${ }^{1^{*}}$, Lisyani BS ${ }^{2}$, Kusmiyati $\mathrm{DK}^{3}$ \\ ${ }^{1}$ Pusat Penelitian dan Pengembangan Sumber Daya dan Pelayanan Kesehatan \\ Balitbangkes, Kemenkes \\ ${ }^{2}$ Bagian/SMF Patologi Klinik Fakultas Kedokteran Universitas Diponegoro/RSUP. \\ Dr. Kariadi Semarang \\ ${ }^{3}$ Program Magister Ilmu Biomedik, Universitas Diponegoro Semarang \\ *E-mail: laninglitbang@gmail.com
}

\begin{abstract}
Blood glucose level could be measured before 2-3 months using glycated haemoglobin (HbAlc). In diabetes mellitus (DM) the size of low-density lipoprotein ( $L D L-K)$ often changes to a small size, called small dense $L D L-K$ sdLDL) which is atherogenic and low high-density lipoprotein (HDL) level. High HbAlc indicates uncontrolled glucose levels and often cause complications of coronary heart disease (CHD). This is a further investigation from the previous one about "The Relationship between HbAlc with LDL and Apo B in DM patients with cardiac complications." This study used analytical, cross-sectional design. Thirty patients DM with CHD complications were examined for HbAlC levels via the Exchange-HPLC ion methods, HDL-K and $L D L-K$ by enzymatic colourimetric methods and apo $B$ by the immunoturbidimetry methods. The relationship between variables was analyzed by the Pearson correlation test.The mean level of HbAlc was $8.72 \%$, male HDL was $35.67 \mathrm{mg} / \mathrm{dl}$, female was $39.57 \mathrm{mg} / \mathrm{dl}$, LDL-K was $110.64 \mathrm{mg} / \mathrm{dl}$, apo B was $111.88 \mathrm{mg} / \mathrm{dl}$ and sdLDL was 1, 02. A strong negative relationship between HbAlc and HDL levels for both men and women with $r$ $=-0.647 ; r=-0.675$ with significance level $p=0.017 ; p=0.008$. Whereas HbAlc with sd-LDL has a weak negative relationship, but not significant ( $r=-0.352 ; p=0.057)$. Hence, lipid profile measurement can be considered to monitor risk of cardiovacular diseases, particularly in those with abnormal blood glucose metabolism.
\end{abstract}

Keeywords: DM with CAD, HbAlc, HDL, sd-LDL, Dr. Kariadi Hospital Semarang

\begin{abstract}
Abstrak
Pemantauan kadar gula 2-3 bulan sebelumnya dapat diukur menggunakan glycated hemoglobin (HbA1c). Pada diabetes melitus (DM) ukuran low density lipoprotein (LDL-K) sering berubah menjadi kecil, yang dinamakan small dence LDL-K (sd-LDL) yang bersifat aterogenik, dan kadar high density lipoprotein (HDL) sering rendah. HbA1c yang tinggi menandakan kadar glukosa tidak terkontrol dan sering menyebabkan salah satu komplikasi ke penyakit jantung koroner (PJK). Penelitian ini merupakan penelitian lanjutan dari penelitian berjudul " Hubungan HbA1c dengan trigliserida dan Apo B pada penderita DM dengan komplikasi penyakit jantung" Studi ini menggunakan desain analitik potong lintang. Tiga puluh pasien DM dengan komplikasi PJK diperiksa kadar HbA1c melalui metoda ion-Exchange HPLC, HDL-K dan LDL-K dengan metoda kolometrik enzimatik dan apo B dengan metoda imunoturbidimetri. Hubungan antar variabel dianalisis dengan uji korelasi Pearson.Hasil penelitian didapatkan laki laki 16 dan perempuan 14 pasien. Kadar rerata HbA1c 8,72\%, HDL laki laki 35,67 mg/dl, perempuan 39,57 mg/dl, LDL-K 110,64 mg/dl, apo B 111,88 mg/dl dan sd-LDL 1,02. Hubungan negatif kuat antara kadar HbA1c dan HDL baik laki laki maupun perempuan dengan $r=-0,647 ; r$ $=-0,675$ dengan tingkat kemaknaan $p=0,017 ; p=0,008$. Sedangkan HbA1c dengan sd-LDL terdapat hubungan negatif lemah, tetapi tidak bermakna ( $\mathrm{r}=-0,352 ; p=0,057)$. Karena itu, pemeriksaan profil lipid dapat dipertimbangkan untuk memantau risiko penyakit kardiovaskular khususnya bagi mereka dengan gangguan metabolisme gula darah.
\end{abstract}

Kata Kunci: DM komplikasi PJK, HbA1c, HDL, sd-LDL, RSUP Dr. Kariadi Semarang 


\section{Pendahuluan}

Diabetes Melitus (DM) merupakan penyakit kronis yang masih menjadi masalah utama di Indonesia. Menurut American Diabetes Association (ADA) 2018, DM adalah suatu kelompok penyakit metabolik dengan karakteristik hiperglikemia yang terjadi karena kelainan sekresi insulin, kerja insulin atau keduaduanya. Penyebab mortalitas dan morbiditas utama pada pasien DM tipe 2 adalah penyakit jantung koroner (PJK). ${ }^{1,2}$ DM yang tidak dikelola dengan baik mengakibatkan komplikasi yang bersifat kronik, salah satunya yaitu komplikasi makroangiopati. Penderita DM memiliki kadar glukosa yang tinggi sehingga dapat meningkatkan viskositas darah. Meningkatnya viskositas darah ini dapat menyebabkan kerja jantung lebih berkerja keras. Selain itu tingginya glukosa akan diiringi pula meningkatnya kadar lemak yang menempel di dinding pembuluh darah. Adanya lemak ini akan menyebabkan menyempitnya pembuluh darah sehingga aliran darah dapat terganggu. Adanya lemak yang menempel juga akan menyebabkan pembuluh darah yang menjadi keras dan penyumbatan pembuluh darah. ${ }^{3}$ Selain itu, orang dewasa yang menderita DM berisiko dua sampai empat kali lebih besar terkena penyakit jantung dari pada orang yang tidak menderita DM. ${ }^{2}$

Glycated hemoglobin (HbA1c) adalah pengendali glikemia jangka panjang. Banyak penelitian dilakukan untuk membuktikan bahwa HbA1c dapat digunakan sebagai penanda untuk meramalkan kejadian dislipidemia di pasien DM tipe 2. Bakuan emas yang digunakan sebagai indeks glikemia di klinik adalah HbA1c. Diabetes Control and Complications Trial (DCCT) menyarankan bahwa kadar HbA1c $<7,0 \%$ dapat mencegah keparahan komplikasi kronik DM. Perkembangan terkini, HbA1c dapat digunakan sebagai petanda untuk menilai predisposisi terhadap penyakit kardiovaskular di pasien DM. ${ }^{4}$
DM tipe 2 punya gambaran profil lipid sering ditemukan peningkatan kadar trigliserida (TG) dan penurunan high density lipoprotein (HDL), sedangkan kadar low density lipoprotein (LDL) tidak banyak berbeda dengan yang ditemukan pada individu yang tidak diabetes, namun didominasi oleh bentuk yang lebih kecil dan lebih padat. ${ }^{5}$ Kadar glukosa yang tinggi juga merangsang pembentukan glikogen dari glukosa, sintesis asam lemak dan kolesterol yang akan mempercepat pembentukan TG dalam hati. Cholesteryl ester transport protein (CETP) memfasilitasi pertukaran TG dari very lowdensity lipoprotein (VLDL) dengan ester kolesterol dari LDL dan HDL. TG di dalam inti LDL dan HDL, dihidrolisis oleh lipase menghasilkan small dense LDL (sdLDL) dan HDL menjadi berukuran lebih kecil. HDL kemudian diekskresikan oleh ginjal, menyebabkan kadar kolesterol HDL dalam darah rendah. Kadar sd-LDL dapat diperkirakan dari rasio low-density lipoprotein-kolesterol/apolipoprotein- $B$

(LDL-K/ApoB). Setiap partikel LDL-K mengandung protein berupa ApoB-100 dan kolesterol sebagai komponen lipid utamanya. Ukuran partikel LDL ditentukan oleh kandungan kolesterol. Hampir 90\% ApoB ada pada fraksi LDL, maka kadar ApoB secara kasar menggambarkan jumlah partikel LDL. ${ }^{6}$

Kelainan lipid seperti peningkatan kolesterol, LDL, TG, penurunan HDL dan kelainan lipoprotein ditambah memburuknya kontrol glikemik, sangat berkontribusi terhadap mortalitas dan morbiditas. Kombinasi hiperglikemia, dislipidemia, dan hipertensi menyebabkan peningkatan PJK. Resistensi insulin, defisiensi insulin relatif, dan obesitas berhubungan dengan profil lipid yang rusak. Penelitian American Diabetes sampai pada kesimpulan bahwa HbA1c <7 $\mathrm{mg} / \mathrm{dl}$ menandakan kadar glukosa darah yang optimal. Manajemen harus fokus pada pengendalian diabetes dan mengelola kadar lipid yang akan mengurangi 
mortalitas dan morbiditas untuk penyakit jantung dan komplikasi diabetes lainnya., ${ }^{7,8}$

Penelitian ini merupakan penelitian berkesinambungan dari penelitian terdahulu, berjudul "Hubungan HbAlc dengan trigliserida dan Apo B pada penderita DM dengan komplikasi jantung koroner". Hasil dari penelitian tersebut adalah terdapat hubungan positif sedang antara $\mathrm{HbA1c}$ dengan Apo B, positif kuat antara $\mathrm{HbA} 1 \mathrm{c}$ dengan trigliserida dan tidak terdapat hubungan bermakna antara HbA1c dengan LDL-K. Perizinan Etik penelitian No.036/EC/FK-RSDK/2015 dikeluarkan oleh FK Universitas Diponegoro dan RSUP dr. Kariadi Semarang. Untuk melanjutkan penelitian yang terdahulu perlu dilakukan penelitian untuk menilai sejauh mana hubungan antara HbA1c dengan HDL dan sd-LDL pada penderita DM dengan komplikasi PJK. Tujuan penelitian ini adalah membuktikan adanya hubungan antara kadar HbA1c dengan kadar HDL dan sdLDL serum pada penderita DM dengan komplikasi PJK. Diharapkan dapat memberikan masukan ilmiah pada penderita DM dengan komplikasi PJK dan informasi kepada masyarakat dengan mengetahui peranan sebenarnya HbA1c, HDL dan sd-LDL untuk mencegah komplikasi yang lebih lanjut.

\section{Metode}

Desain penelitian ini adalah potong lintang. Populasinya adalah penderita DM dengan komplikasi PJK di RS Kariadi Semarang, di mana pasien menderita DM terlebih dahulu dan kemudian mengalami komplikasi PJK. Bila memenuhi syarat maka diambil sebagai sampel penelitian. Subyek penelitian adalah penderita DM dengan komplikasi PJK yang berobat di Poli Penyakit Dalam di RS Kariadi Semarang antara bulan Agustus 2014 hingga Februari 2015. Sampel penelitian ini berjumlah 30 pasien. Kriteria inklusi: pria maupun wanita berusia dewasa (26 sampai 60 tahun), kadar haemoglobin normal (tidak anemia, wanita $=12 \mathrm{~g} / \mathrm{dl}$; laki-laki=13 g/dl), pemeriksaan fisik tiroid tidak ada kelainan, tensi normal: sistol $\leq$ $140 \mathrm{mmHg}$ dan diastole $\leq 90 \mathrm{mmHg}$, riwayat pola makan dan minum normal, suhu tubuh normal $\left(36-37,5 \mathrm{C}^{0}\right)$. Kriteria eksklusi: cholestatic jaundice, spesimen lisis, lipemik dan ikterik, adanya $\mathrm{Hb}$ varian.

Data yang dikumpulkan meliputi catatan medik, anamnesis dan pemeriksaan laboratorium. Pengambilan subyek dilakukan dengan consecutive sampling. Berdasarkan perhitungan subyek menggunakan rumus uji korelasi. Sampel yang dipakai adalah sampel minimum penelitian adalah 30 pasien . Variabel bebas dalam penelitian ini adalah HbA1c dan variabel terikat adalah HDL, LDL-K dan sd-LDL. Definisi operasional HbA1c adalah kadar HbA1c dalam darah EDTA yang dideteksi menggunakan metode : ionexchange $H P L C$, langsung diperiksa setelah diambil darah. HDL, LDL-K dan sd-LDL adalah kadar HDL, LDK-K dan sd-LDL dalam serum yang diukur sesudah 10-12 jam setelah makan. Metode HDL dan LDK-K menggunakan pengukuran kolometrik enzimatik, sedangkan sd-LDL menggunakan rasio LDL-K dan Apo B, Apo $\mathrm{B}$ diukur dengan immunoturbidimetri. Untuk parameter LDL-K dan HDL berasal dari serum yang disimpan pada suhu $20^{\circ} \mathrm{C}$. Sebelum pengukuran dilakukan pemantapan mutu internal dengan menggunakan kontrol normal dan abnormal. Laboratorium di RS Kariadi juga mengikuti pemantapan mutu eksternal. Hasil yang keluar dari alat diverifikasi oleh tiga orang yang berbeda. Jika hasil ada yang meragukan akan di telusuri termasuk juga dilakukan pemeriksaan ulang (duplo).

Analisis data menggunakan program statistik komputer perangkat lunak (SPSS versi 17). Analisis statistik untuk melihat hubungan antara kadar HbA1c dengan HDL, LDL-K dan sd-LDL pada penderita DM dengan komplikasi PJK dengan uji korelasi Pearson yang sebelumnya diuji 
kenormalan data menggunakan uji Shapiro-Wilk, apabila berdistribusi tidak normal dilakukan transformasi dengan log 10. Uji normalitas data sudah sesuai kaidah statistik.

\section{Hasil}

Data karakteristik (Tabel 1) menunjukkan bahwa rata rata sebagian responden adalah laki-laki. Nilai rerata HbA1c 8,72 mg/dl, dan nilai rerata HDL pada laki laki lebih rendah daripada perempuan. Nilai rerata kadar LDK-K hampir sama dengan nilai rerata kadar apo B dengan kadar rerata sd-LDL pada 1,02. Karakteristik pada pasien DM dengan komplikasi PJK, semua abnormal kecuali LDK-K tetapi sd-LDL lebih kecil.

Tabel 1. Data karakteristik subjek penelitian

\begin{tabular}{lc}
\hline Karakteristik Subjek & \\
\hline Laki-laki & $53,3 \%^{\mathrm{a}}$ \\
Perempuan & $46,7 \%$ \\
Umur laki-laki (tahun) & $55,38 \pm 4,54^{\mathrm{b}}$ \\
Umur perempuan (tahun) & $55,43 \pm 6,39$ \\
HbA1c (\%) & $8,72 \pm 1,73$ \\
HDL (mg/dl) & $37,67 \pm 8,06$ \\
$\quad \quad \quad$ Laki-laki & $35,62 \pm 7,44$ \\
$\quad$ - Perempuan & $39,57 \pm 8,41$ \\
LDL-K (mg/dl) & $110,64 \pm 32,10$ \\
$\quad$ Apo B (mg/dl) & $111,88 \pm 34,49$ \\
Sd-LDL & $1,02 \pm 0,22$ \\
\hline \multicolumn{2}{c}{${ }^{\mathrm{a} P e r s e n t a s e ~ d a r i ~ j u m l a h ~ t o t a l ~ s a m p e l ~ 30 ~}$}
\end{tabular}

Hasil pemeriksaan HbA1c sesuai target pengendalian glukosa menurut ADA tahun 2018 (Tabel 2) menunjukkan bahwa pengendalian glukosa tidak terkontrol lebih banyak daripada yang terkontrol. Data lain di Tabel 2 juga menunjukkan lebih besarnya proporsi responden dengan dislipidemia dibandingkan mereka tanpa dislipidemia. Indikasi dislipidemia tersebut tercermin dari kadar HDL dan sd-LDL yang rendah serta kadar LDL-K dan apo B yang tinggi, yaitu: proporsi laki-laki dengan kadar HDL-K $<40 \mathrm{mg} / \mathrm{dl}$ dan perempuan dengan kadar HDL-K $<50$ $\mathrm{mg} / \mathrm{dl}$ melebihi separuh dibandingkan mereka dengan kadar HDL-K yang normal untuk masing-masing jenis kelamin. Hal yang serupa berlaku juga untuk parameter LDL-K dan apo B. Selain itu, persentase responden dengan nilai sd-LDL $<1,2$ melebihi mereka dengan nilai sd-LDL $\geq$ 1,2. Terkait hal ini, semakin kecil nilai ukuran sd-LDL, maka potensi aterogenisitas juga semakin besar. 
Tabel 2. Hasil pemeriksaan HbA1c, HDL, LDL-K, Apo B dan sd-LDL

\begin{tabular}{lcc}
\hline Pemeriksaan laboratorium & Jumlah & Persentase $(\%)$ \\
\hline HbA1c $(\%)$ & 6 & \\
$<7$ & 24 & 20 \\
$\geq 7$ & 12 & 80 \\
HDL laki-laki (mg/dl) & 4 & 75 \\
$<40$ & & 25 \\
$\geq 40$ & 13 & \\
HDL perempuan (mg/dl) & 1 & 92,9 \\
$<50$ & & 7,1 \\
$\geq 50$ & 13 & 43,3 \\
LDL-K (mg/dl) & 17 & 56,7 \\
$<100$ & & \\
$\geq 100$ & 14 & 46,7 \\
Apo B (mg/dl) & 16 & 53,3 \\
$<105$ & & \\
$\geq 105$ & 10 & 33,3 \\
Sd-LDL & 20 & 66,7 \\
$\geq 1,2$ & & \\
$<1,2$ & & \\
\hline
\end{tabular}

Data kadar HDL dan sd-LDL berdasarkan kategori pengendalian kadar glukosa (HbA1c) di Tabel 3 menunjukkan bahwa parameter kadar HDL rata-rata laki-laki dan perempuan serta nilai sd-LDL lebih baik pada mereka dengan DM yang terkontrol (HbA1c <7\%) dibandingkan mereka yang kadar gula darahnya tidak terkontrol.

Tabel 3. Kadar HDL dan sd-LDL pada target pengendalian glukosa.

\begin{tabular}{lccc}
\hline Kadar HbA1c & \multicolumn{3}{c}{ Rerata \pm SD } \\
\hline & $\begin{array}{c}\text { Kadar HDL Laki } \\
\text { laki }(\mathrm{mg} / \mathrm{dl})\end{array}$ & $\begin{array}{c}\text { Kadar HDL } \\
\text { perempuan }(\mathrm{mg} / \mathrm{dl})\end{array}$ & Sd-LDL \\
\hline $\begin{array}{l}\text { HbA1c }<7 \% \\
(\mathrm{~N}=6)\end{array}$ & $39,75 \pm 5,85$ & $48,5 \pm 0,71$ & $1,07 \pm 0,12$ \\
$\begin{array}{l}\mathrm{HbA1c} \geq 7 \% \\
(\mathrm{~N}=24)\end{array}$ & $34,92 \pm 0,82$ & $38,08 \pm 8,16$ & $1,00 \pm 0,24$ \\
\hline
\end{tabular}

Dari hubungan antara kadar HbA1c dengan HDL-K dan sd-LDL dengan uji korelasi Pearson (Tabel 4) menunjukkan hubungan negatif kuat antara kadar HbA1c dan HDL baik laki laki maupun perempuan dengan tingkat korelasi sebesar -0,647 pada laki-laki dan perempuan sebesar -0,675, Kedua hubungan antara
HbA1c dengan HDL pada laki-laki dan perempuan mempuyai tingkat kemaknaan sebesar $p=0,017$ pada laki-laki dan $p=0,008$ pada perempuan. Terdapat hubungan negatif lemah antara kadar HbA1c dengan sd-LDL dengan derajat korelasi sebesar -0,352, tetapi tidak bermakna $(p=0,057)$ (Gambar 1). 
Tabel 4. Hubungan kadar HbA1c dengan kadar HDL, sd-LDL pada penderita DM dengan komplikasi PJK.

\begin{tabular}{llc}
\hline Hubungan & $\boldsymbol{r}$ & $\boldsymbol{p}$ value \\
\hline Kadar HbA1c dengan kadar HDL & & \\
$-\quad$ Laki-laki & $-0,647$ & 0,017 \\
$-\quad$ Perempuan & $-0,675$ & 0,008 \\
Kadar HbA1c dengan kadar sd-LDL & $-0,352$ & 0,057 \\
\hline
\end{tabular}

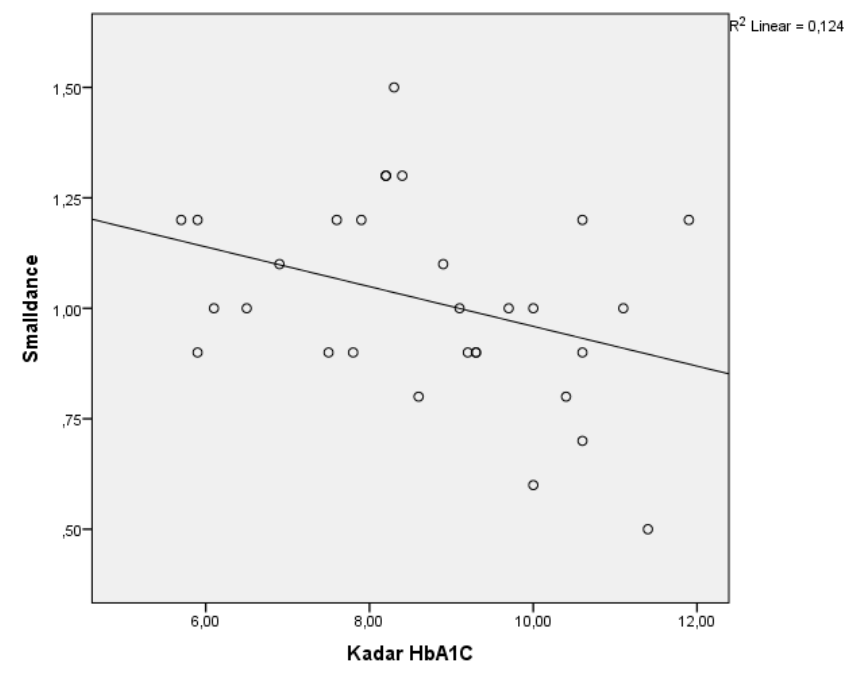

Gambar 1. Hubungan HbA1c dengan sd-LDL pada penderita DM dengan komplikasi PJK

\section{Pembahasan}

Distribusi jenis kelamin pada penelitian ini laki-laki lebih banyak daripada perempuan, laki-laki sebanyak $53,3 \%$, perempuan $46,7 \%$ dengan rerata usia laki dan perempuan 55 tahun. Penelitian ini hampir sama dengan Shigemasa Tani et al, penderita DM dengan PJK lebih banyak laki laki dari pada perempuan. ${ }^{9}$ Pada beberapa penelitian, rata rata usia terkena PJK pada pasien DM di atas 50 tahun, seperti pada penelitian Wenhui Zhao et al, Jennifer $\mathrm{K}$ et al. ${ }^{10,11}$ Secara teoretis, pada laki-laki morbiditas akibat PJK adalah dua kali lebih besar daripada wanita dan terjadi hampir 10 tahun lebih dini dibandingkan wanita. Hal ini terkait dengan adanya estrogen endogen yang bersifat protektif pada wanita, namun setelah menopause insiden PJK dengan cepat meningkat dan sebanding dengan laki-laki. ${ }^{6}$ Studi sistematik literatur oleh Thomas R. Einarson dkk juga menyebutkan prevalensi PJK pada laki-laki lebih tinggi daripada perempuan. $^{12}$

Dari data penelitian diatas, didapatkan bahwa rata rata dari HbA1c, HDL laki dan perempuan, LDK-K, apoB dan sd-LDL lebih tinggi dari normal dengan nilai HbA1c sebesar 8,72 mg/dl, HDL pada laki laki sebesar 35,67 $\mathrm{mg} / \mathrm{dl}$ dan perempuan sebesar 39,57 mg/dl, LDK-K sebesar 110,64 mg/dl, apoB sebesar 111,88 mg/dl dan sd-LDL sebesar 1,02. Berdasarkan Konsensus PERKENI tahun 2015 penderita DM yang tidak dapat mengontrol 
kadar glukosa darah mudah terjadinya komplikasi kardiovaskular. ${ }^{13}$ Penelitian ini juga hampir sama dengan penelitian Aicha Laissaoui et al, HbA1c sebagai prediktor dislipidemia. ${ }^{14}$

Glukosa dan asam lemak adalah dua sumber energi terbesar dalam tubuh. Gangguan salah satu unsur tersebut akan mempengaruhi metabolisme lainnya, misalnya pada DM gangguan metabolisme gula dihubungkan dengan dislipidemia. ${ }^{6}$ Pasien DM sering memiliki kadar kolesterol total yang relatif normal, namun sering mengalami dislipidemia aterogenik yang ditandai dengan peningkatan TG, konsentrasi kolesterol HDL yang rendah, dan partikel LDL kecil yang padat. Pembentukan LDL kecil merupakan hal yang sangat penting sebagai penentu utama dari ApoB. LDL kecil maupun glikasi LDL dikaitkan dengan peningkatan kerentanan terhadap oksidatif, memacu makrofag untuk membuat sel busa pada proses aterosklerotik. Selain itu, pasien sering menunjukkan peningkatan ApoB (kisaran referensi 55-140 mg / dL pada pria dan 55-125 mg / dL pada wanita) dan konsentrasi kolesterol non-HDL. Bukti luas menunjukkan bahwa pada pasien diabetes, TGs tinggi, kolesterol HDL rendah, ApoB dan LDL kecil padat merupakan prediktor untuk PJK. ${ }^{15,16}$

Data subjek penelitian ini menunjukkan terdapat hubungan negatif kuat antara kadar HbA1c dan HDL baik laki laki maupun perempuan dengan $r=$ 0,$647 ; \quad r=-0,675$ dengan tingkat kemaknaan $p=0,017 ; \quad p=0,008$. Hubungan HbA1c dengan HDL, baik lakilaki dan perempuan negatif kuat, artinya semakin tinggi kadar HbAlc semakin rendah kadar HDL. Hasil penelitian ini sesuai dengan penelitian dilakukan oleh Aditya Devi Ratnasari tahun $2016^{1}$ menunjukkan hubungan negatif sedang antara HbA1c dengan kadar HDL pada pasien diabetes melitus tipe $2(\mathrm{p}=0,002, \mathrm{r}$ $=-0,488) .{ }^{17}$ Penelitian Prithwiraj Bhattacharjee dkk tahun 2018, menunjukkan hubungan negative kuat $r=-$ 0674. ${ }^{18}$

Hubungan HbA1c dengan sd-LDL pada penelitian ini terdapat hubungan negatif lemah dengan $r=-0,352$, tetapi tidak bermakna $(p=0,057)$. Semakin tinggi kadar HbA1c semakin tinggi sdLDL, tetapi hal ini tidak bermakna. Teori menyatakan pada pasien DM mudah sekali terbentuk sd-LDL yang berukuran kecil dan padat (diameter $<25,5 \mathrm{~nm}$ dan densitas $1,044-1,063 \mathrm{~g} / \mathrm{mL}$ dan dikenal sebagai LDL aterogenik karena mudah masuk ke dinding arteri dan teroksidasi. Sd-LDL mempunyai afinitas rendah terhadap reseptor LDL akibatnya lebih lama dalam sirkulasi. Selain itu, sd-LDL juga dapat menyebabkan disfungsi endotel sehingga mudah menyebabkan PJK. ${ }^{19}$ Hal tersebut tidak lepas dari peran limfosit $\mathrm{T}$ dan monosit. Monosit akan melintasi rintangan endotel dan masuk ke dalam ruang subendotel sebagai respons keberadaan molekul adhesi. Monosit yang terpacu oleh inflamasi, di dalam dinding pembuluh darah akan membentuk reaksi inflamasi dan berdiferensiasi menjadi makrofag. Makrofag akan mudah menangkap partikel lipid (sd-LDL) yang ada di dinding pembuluh darah akibat gangguan fungsi endotel sehingga membentuk sel busa yang memudahkan pembentukan arteri aterogenesis, yang kemudian akan mengakibatkan PJK. $^{20}$ Dislipidemia diabetik atau dislipidemia aterogenik ditandai dengan HDL rendah, TG tinggi dan sd-LDL tinggi. Oleh karena itu, langkah awal pasien diabetes dengan dislipidemia diperlukan intervensi dini untuk meminimalkan risiko meninggal karena jantung. $^{21}$

Keterbatasan penelitian ini antara lain jumlah sampel yang tidak terlalu besar dan penentuan DM dengan komplikasi PJK berdasarkan wawancara pada saat pengumpulan data dilakukan. Dalam penelitian ini, hubungan $\mathrm{HbA1c}$ dengan sd-LDL berkorelasi negatif, yang seharusnya korelasi positif. Saat artikel ini 
disusun, penulis belum menemukan penelitian lain yang hasilnya serupa dengan studi ini. Karena itu, untuk penelitian serupa di masa mendatang, jumlah sampel dapat ditambah sehingga dapat merepresentasikan populasi yang lebih luas. Selain itu, indikator lain seperti recall diet, faktor perilaku, pemeriksaan EKG dan parameter biomedis lainnya dapat dimasukkan untuk menyingkirkan kemungkinan penyakit penyerta lainnya dan meminimalkan risiko bias saat pengumpulan data.

\section{Kesimpulan}

Terdapat hubungan korelasi negatif kuat yang bermakna antara kadar HbAlc dengan kadar HDL dan korelasi negatif lemah antara HbA1c dengan sd-LDL meskipun tidak bermakna pada pasien DM dengan komplikasi PJK di Rumah Sakit Kariadi Semarang. Dari hasil ini, kontrol kadar lipid darah dapat dipertimbangkan untuk memantau risiko penyakit kardiovaskular pada mereka dengan gangguan metabolisme gula darah.

\section{Saran}

Pasien DM yang tidak terkontrol kadar gula darahnya, akan mudah mengalami komplikasi lebih lanjut, salah satunya PJK. Oleh karena itu, pasien dengan DM harus menjaga kadar gula darahnya normal dengan cara $3 \mathrm{~J}$ yaitu pengaturan jadwal pola makan, jumlah makan, dan pemilihan jenis makanan. Selain itu, pasien juga perlu berolah raga teratur, mengendalikan tekanan darah, menjaga pola makan dan berat badan. Penderita DM dengan komplikasi PJK pada penelitian ini juga memerlukan kontrol rutin dengan pemeriksaan laboratorium misalnya, kadar $\mathrm{HbA} 1 \mathrm{c}$, HDL, apo B, sd-LDL dan lain-lain

\section{Ucapan Terima Kasih}

Terima kasih kepada RSUP Dr. Kariadi Semarang beserta tim dan tim yang membantu dalam proses pemeriksaan laboratorium, Dr. dr. Purwanto AP, SpPK( K), dr. Indrayani, M.Si.Med, SpPK dan dr. Andreas, SpPK.

\section{Daftar Rujukan}

1. American Diabetes Association (ADA). Classification and diagnosis of diabetes: standards of medical care in diabetes 2018. Diabetes Care 2018;41(Suppl. 1):S13-S27

2. Yuliani F, Oenzil F, Iryani. Hubungan berbagai faktor risiko terhadap kejadian penyakit jantung coroner pada penderita diabetes melitus tipe 2. Journal Kesehatan Andalas 2014;3(1):37-40.

3. Utami NL, Azam M. Kejadian penyakit jantung coroner pada penderita diabetes melitus. HIGEIA 2019;3(2):311-23.

4. Eriskawati T, Tahono, Diah MI. Hubungan glycated albumin dengan angka banding kolesterol LDL/LDH di diabetes melitus tipe 2.IJCPM 2015;22(1):16-21.

5. Ratnasari AD, Indranila KS, Retnoningrum D. Hubungan antara HbA1c dengan kadar HDL pada pasien diabetes melitus tipe 2. JKD 2017;6(2):141-7.

6. Driyah S. Hubungan HbA1c dengan trigliserida, LDL-K dan apo B pada penderita DM dengan komplikasi jantung koroner. Semarang 2015. Universitas Diponegoro.

7. Devkar V, Desai P, Prajapati P, Rao S, Desai A. Correlation between glycated hemoglobin and dyslipidemia in patients with type 2 diabetes mellitus in a tertiary care hospital, Maharashtra, India. International Journal of Scientific Study 2016;4(6):121-4.

8. Sirsikar M, Supriya, Mohanty1 S, Pinnelli VBK. Role of glycated hemoglobin (HbA1c) as a dual marker to predict glycemic status and dyslipidemia in type II diabetes mellitus. Int $\mathbf{J}$ Res Med Sci 2016;4(10):4524-29.

9. PERKENI, editor. Konsensus : pengelolahan dan pencegahan diabetes melitus tipe 2 di Indonesia 2015. Jakarta: PERKENI; 2015.

10. Tani S, Yagi T, Atsumi W, Kawauchi K, Matsuo R, Hirayama A. Relation between low-density lipoprotein cholesterol/apolipoprotein $\mathrm{B}$ ratio and triglyceride-rich lipoproteins in patients with coronary artery disease and type 2 diabetes mellitus: a cross- 
sectional study. Cardiovasc Diabetol 2017;16(123):1-13

11. Zhao W, Katzmarzyk P, Horswell R, Wang Y, Johnson J, Hu G.HbA1c and coronary heart disease risk among diabetic patients. Diabetes Care 2014;37:28-35

12. Pai JK, Cahill LE, Hu FB, Rexrode KM, Manson JE, Rimm EB. Hemoglobin A1c is associated with increased risk of incident coronary heart disease among apparently healthy, nondiabetic men and women. J Am Heart Assoc 2018;2(2):1-8.

13. Einarson TR, Acs A, Luwig C, Panton UH. Prevalensi of cardiovascular disease in type 2 diabetes: a systematic literature review of scientific evidence from across the word in 2007-2017. Cardiovasc Diabetol 2018. 17(83);1-19.

14. Laissaoui A, Allem R, Azzoug S, Yahiaoui, Belouazni A. HbA1c as a predictor of dyslipidemia in algerian type 2 diabetic patients. Rom J Diabetes Nutr Metab Dis 2016. 23(2):139-46.

15. Rees A. Excess cardiovascular risk in patients with type 2 diabetes: do we need to look beyond LDL cholesterol. $\mathrm{Br} \mathrm{J}$ Diabetes Vasc Dis 2014;14:10-20.

16. Marufi R, Rosita L. Hubungan dyslipidemia dan kejadian penyakit jantung coroner. JKKI 2014;6(1):47-53.

17. Ratnasari AD, Indranila KS, Retnoningrum2 D. Hubungan antara HbA1c dengan kadar HDL pada pasien diabetes melitus tipe 2. JKD 2017;6(2):141-7.

18. Bhattacharjee $P$, Das $P$, Nath BK, Basumatary A, Dwijen Das D. HbA1c and its correlation with lipid profile in acute myocardial infarction. IJCMR 2018;5(4):13-6.

19. Liana P. Peran small-dense low density lipoprotein terhadap penyakit kardiovaskular. Jurnal kedokteran dan kesehatan 2014;1(1): 67-72.

20. Indranila K, Samsuria, Adninta L. Pemeriksaan tingkat sd-LDL serum sebagai petanda diagnostik stenosis koroner. Indonesian Journal of Clinical Pathology and Medical Laboratory 2015;22(1):9-15.

21. Sultania S, Thakur D, Kulshreshtha M. Study of lipid profile in type 2 diabetes mellitus patients and its correlation with HbA1c. IJCMR 2017;4(2):437-9. 